\title{
Are Small Adrenal Incidentalomas Solely a Radiological Finding?
}

Mehmet Asik, Mustafa Eroglu, Hakan Turkon, Emine Binnetoglu, Fahri Gunes, Hacer Sen, Gokhan Erbag, Yeliz Yilmaz, Mustafa Sahin and Kubilay Ukinc. Çanakkale Onsekiz Mart University Faculty of Medicine Department of Endocrinology and Metabolism, Internal Medicine, Biochemistry, Çanakkale, Turkey•

\section{Objective}

The criteria defining the threshold size of adrenal incidentaloma (AI) are greater than $1 \mathrm{~cm}$ diameter. However, data about $\mathrm{AI} \leq 1 \mathrm{~cm}$ diameter is scant. The aim of this study is to evaluate function of adrenal masses $\leq 1 \mathrm{~cm}$ and to compare them with adrenal masses $>1 \mathrm{~cm}$ as well as to understand the possible utility of determining salivary cortisol in diagnosis of SCS in patients with AI.

\section{Methods}

The study included 137 consecutive patients with AI (38 and 99 AI at $\leq 1 \mathrm{~cm}$ and $>1 \mathrm{~cm}$, respectively).

\section{Results}

SCS was $5.3 \%, 17.2 \%$ in $\mathrm{AI} \leq 1 \mathrm{~cm}$ and $>1 \mathrm{~cm}$ diameter, respectively. The patients with $>1 \mathrm{~cm} \mathrm{AI}$ had a higher prevalence of SCS and primary hyperaldosteronism than patients with $>1 \mathrm{~cm} \mathrm{AI} \mathrm{did,} \mathrm{but}$ they did not differ significantly. The prevalence of diabetes and hypertension was high both in nonfunctional AI with $\leq 1$ and $>1$ patients and showed no significant difference between two groups. Using a cut-off of $0.33 \mu \mathrm{g} / \mathrm{dL}$ for midnight salivary cortisol (MNSC), sensitivity, specificity, values of positive and negative predictivity for diagnosis of SCS were $58 \%, 86 \%, 40.7 \%$ and $91.8 \%$, respectively.

\section{Conclusion}

The AI $\leq 1 \mathrm{~cm}$ harboured SCS as was the case in $\mathrm{AI}>1 \mathrm{~cm}$. Similar to AI $>1 \mathrm{~cm}$, non-functional AI $\leq 1 \mathrm{~cm}$ also had higher prevalence of diabetes and hypertension. Furthermore, MNSC in patients with AI was found comparable with midnight serum cortisol in diagnoses of SCS.

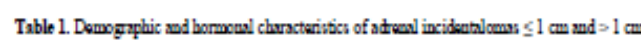

\begin{tabular}{|c|c|c|c|}
\hline & $\begin{array}{l}\text { AI } \leq 1 \mathrm{~cm} \\
(\mathrm{n}=38)\end{array}$ & $\begin{array}{c}\text { AI }>1 \mathrm{~cm} \\
(\mathrm{n}=92)\end{array}$ & $\mathrm{p}$ \\
\hline Geuder (IF) & $174.7 \%$ & $447.8 \%$ & $\mathrm{NS}$ \\
\hline Age & $55.76=13.34$ & $58.25=10.76$ & $\mathrm{Ns}$ \\
\hline BMII $\left(1 \mathrm{~g} / \mathrm{m}^{2}\right)$ & $29.79=6.85$ & $30.17=5.64$ & $\mathrm{NS}$ \\
\hline wHR & $0.91=0.17$ & $0.93=0.1$ & NS \\
\hline $\operatorname{Size}(\mathrm{mm})^{*}$ & $8.81=4.74$ & $22.71=8.4$ & $=0.001$ \\
\hline $\mathrm{FPG}$ (mg/di) & $106.68=29.06$ & $109.63=43.7$ & $\mathrm{NS}$ \\
\hline TC (mpdit) & $206.87 \pm 46.47$ & $208.51=47.8$ & NS \\
\hline $\mathrm{HDL}$ (me/dL) & $51.24=11.72$ & $51.43=15.7$ & $\mathrm{NS}$ \\
\hline LDL (me/dil) & $133.11=45.36$ & $133.87=36.24$ & $\mathrm{NS}$ \\
\hline $\mathrm{TG}$ (mp/dI) & $154.5=83.2$ & $149.33=70.99$ & $\mathrm{NS}$ \\
\hline $\mathrm{ACTH}(\mathrm{pg} \operatorname{in})$ & $21.04=13.93$ & $18.26=12.89$ & NS \\
\hline DHEAS ( $\mu$ dII) & $93.55=66.45$ & $89.69=59.93$ & $\mathrm{NS}$ \\
\hline $\mathrm{HT}(\mathrm{e} / \%)$ & $1847.4 \%$ & $4548.9 \%$ & NS \\
\hline $\operatorname{DM}(\mathrm{w} \%)$ & $821.1 \%$ & $2628.3 \%$ & NS \\
\hline $\operatorname{scs}\left(\mathrm{s}^{1 / 6}\right)$ & $2 / 53 \%$ & $11 / 12 \%$ & $\mathrm{NS}$ \\
\hline PHA $(\mathbf{w} / 6)$ & - & $22.2 \%$ & $\mathrm{Ns}$ \\
\hline Ph & . & . & \\
\hline
\end{tabular}

